\title{
EFEKTIVITAS EKSTRAK ETANOL BIJI PEPAYA TERHADAP JAMUR Colletroticum acutatum J.H. Simmonds PADA BUAH CABAI (Capsicum annuum L. )
}

\author{
Chetrine Della Crysta ${ }^{1}$, Yulianty ${ }^{1}$, Wawan A. Setiawan' ${ }^{1}$, Martha L. Lande ${ }^{1}$ \\ ${ }^{1}$ Jurusan Biologi, Fakultas Matematika dan Ilmu Pengetahuan Alam, Universitas Lampung
}

[e-mail korespondensi: chetrinedella12@gmail.com]

\begin{abstract}
Efektivitas Ekstrak Etanol Biji Pepaya Terhadap Jamur Colletroticum acutatum Pada Buah Cabai ( Capsicum annuum L. ).

This study aims to study the effectiveness of papaya seed ethanol extract as a natural fungicide on the red chili fruit supported by the fungus Colletotricum acutatum which causes anthracnose disease. This research was conducted in January to February 2020, at the Laboratory of Botany, Department of Biology FMIPA University of Lampung. This research was used by using Randomized Block Design (RBD), with 3 replications and replications as a group. Papaya seed extract concentration consists of, $0 \%, 1 \%, 2 \%, 3 \%, 4 \%, 5 \%$. The parameters observed were the occurrence of disease, spotting diameter, disease severity, and weight loss of red chili. Result's research shows that a $5 \%$ concentration is the best extract for suppressing the occurrence and severity of disease, compared to other concentrations.
\end{abstract}

Keywords: Anthracnose, Red Chili Pepper (Capsicum annuum L.), papaya seed extract (Carica papaya L.).

\section{Abstrak :Efektivitas Ekstrak Etanol Biji Pepaya Terhadap Jamur Colletroticum acutatum Pada Buah Cabai (Capsicum annuum L. ).}

Penelitian ini bertujuan untuk mengetahui efektifitas ekstrak etanol biji pepaya sebagai fungisida alami pada buah cabai merah yang terinfeksi jamur Colletotricum acutatum penyebab penyakit antraknosa. Penelitian ini dilaksanakan pada bulan Januari sampai Februari 2020, di Laboratorium Botani Jurusan Biologi FMIPA Universitas Lampung. Penelitian ini digunakan dengan menggunakan Rancangan Acak Kelompok (RAK), dengan 3 kali ulangan dan ulangan sebagai kelompok. Konsentrasi ekstrak biji pepaya terdiri atas, $0 \%, 1 \%, 2 \%, 3 \%, 4 \%, 5 \%$. Parameter yang diamati adalah keterjadian penyakit, diameter bercak, keparahan penyakit, dan susut bobot buah cabai merah. Hasil penelitian menunjukan bahwa konsentrasi $5 \%$ merupakan ekstrak yang terbaik untuk menekan keterjadian dan keparahan penyakit, dibandingkan dengan konsentrasi yang lain.

Kata Kunci : Antraknosa, Cabaai Merah (Capsicum aannuum L.), Ekstrak Biji Pepaya (Carica papaya L.).

\section{PENDAHULUAN}

Cabaimerah (Capsicum annuum L.) merupakan salah satu komoditas sayuran yang banyak dikonsumsi oleh masyarakat Indonesia, baik sebagai penyedap makanan maupun untuk pemenuhan gizi (Setiadi, 2011).

Tingkat kesuburan tanah yang rendah, serta banyaknya serangan organism pengganggu tanaman yaitu hama dan penyakit. Penyakit yang disebabkan oleh jamur yang sering ditemukan pada tanaman cabai diantaranya adalah penyakit busuk buah dan bercak ranting yang disebabkan oleh jamur Colletotrichum 
acutatum dan penyakit bercak daun Cercospora (Fuadidan Yusuf, 2005).

Jamur Colletotrichum acutatum adalah jamur atau fungi bersifat patogen yang menyebabkan busuk buah. Selain pada buah, jamur ini juga menyerang daun dan batang bahkan pasca panen. Colletotrichum acutatum menyebabkan penyakit antraknosa pada sayuran dan buah, sehingga dapat menurunkan kualitas dan kuantitas tanaman tersebut (Ainy, 2015).

\section{METODE}

Penelitian ini dilakukan pada bulan Januari sampai Februari 2020 di Laboratorium Botani Jurusan Biologi FMIPA Universitas Lampung.

Penelitian ini menggunakan Rancangan Acak Kelompok (RAK) dengan 3 kali ulangan dengan perlakuan pemberian ekstrak biji pepaya $0 \%, 1 \%, 2 \%, 3 \%$, $4 \%$, dan 5\%. Masing - masing perlakuan diulang sebanyak 3 kali ulangan.

Pelaksanaan penelitian :

1. Pembuatan Potato Dextrose Agar (PDA)

2. Pembuatan biakan murni jamur Colletotrichum sp

3. Pembuatan Suspensi Konidia Jamur

4. Pembuatan ekstrak biji Pepaya Cabai di sterilisasi dengan alkohol $70 \%$ kemudian direndam kedalam ekstrak biji pepaya dengan konsentrasi masing-masing $0 \%, 1 \%$, $2 \%$, 3\%, 4\%, dan 5\%, selama 10 menit, kemudian dikering anginkan. Kemudian buah cabai di inokulasi dengan metode suntik $0,1 \mathrm{ml}$ konidia Colletroticum sp dan inkubasi selama 8 hari. Dan dilakukan pengamatan pada hari ke 3 sampai ke 8 , untuk mengamatai gejala yang muncul.

Pengamatan dilakukan pada dua minggu setelah aplikasi ekstrak biji pepaya karena pada saat itu gejala pertama kali muncul. Intensitas penyakit adalah tingkat kerusakan buah cabai karena adanya serangan pathogen atau

adanya penyakit. Intensitas penyakit terdiri dari keterjadian penyakit

(disease incidence) dan keparahan penyakit (disease severity),

Sehingga peubah yang diamati yaitu :

1. Keterjadian penyakit antraknosa pada tanaman cabai merah

$$
T P=\frac{n}{N} x 100 \%
$$

$$
\begin{aligned}
& \mathrm{TP}=\text { Keterjadianpenyakit }(\%) \\
& \mathrm{n}=\text { Jumlahbuah cabai yang } \\
& \text { terinfeksi / bergejala } \\
& \mathrm{N}=\text { Jumlah total buah cabai yang } \\
& \text { diamati }
\end{aligned}
$$

2. Keparahan penyakit antraknosa pada tanaman cabemerah

$$
K P=\frac{\sum(n x v)}{n x v} 100 \%
$$

$\mathrm{KP}=$ Keparahan serangan (\%)

$\mathrm{N}=$ Banyaknya buah cabai dalam setiap kategori serangan

$\mathrm{N}=$ Jumlah buah cabai yang diamati

$\mathrm{v}=$ Nilai numeric untuk tiap kategori serangan

$\mathrm{V}=$ Nilai skor tertinggi

Skor penyakit yang digunakan adalah sebagai berikut :

Skor penyakit 0

Skor penyakit 1

Skor penyakit 3

Skor penyakit 4 tidak ada infeksi

Luas permukaan

buah cabai atau bagian buah cabai yang terserang mencapai $10 \%$

Luas permukaan buah cabai atau bagian buah cabai yang terserang lebih besar dari $10 \%$ sampai $25 \%$. Luas permukaan buah cabai atau bagian buah cabai yang terserang lebih besar dari $25 \%$ sampai $50 \%$. Luas permukaan buah cabai atau 
bagian buah cabai yang terserang lebih besar dari $50 \%$.

\section{Susut bobot buah}

Perhitungan susut bobot buah dilakakun dengan mengurangi berat basah pada buah cabai dengan berat kering yang sudah diberi perlakuan. Satuan pengukuran susut bobot buah yaitu gram (gr).
Analisis data dilakukan terhadap keterjadian, keparahan penyakit, berat basah, dan berat kering buah cabai. Rancangan percobaan berupa Rancangan Acak Kelompok (RAK). Konsentrasi ekstrak biji pepaya dengan 6 taraf $0 \%(\mathrm{~A} 0), 1 \%(\mathrm{~A} 1), 2 \%(\mathrm{~A} 2)$, $3 \%$ (A3), 4\% (A4), dan 5\% (A5). Dilakukan uji homogenitas (bartlet), dan dilanjutkan dengan uji Beda Nyata Terkecil (BNT) pada taraf 5\%.

HASIL

Tabel 1. Uji BNT diameter bercak hari ke-6 dan hari ke-8 pada buah cabai merah yang diperlakukan dengan berbagai konsentrasi ekstrak biji pepaya.

\begin{tabular}{|c|c|c|c|c|c|c|c|c|c|c|}
\hline \multirow{2}{*}{ Perlakuan } & \multirow{2}{*}{ M } & \multirow{2}{*}{ \pm} & \multirow{2}{*}{ Sd } & \multicolumn{2}{|l|}{ Sig } & \multirow{2}{*}{ M } & \multirow[b]{2}{*}{ \pm} & \multirow{2}{*}{ Sd } & \multicolumn{2}{|l|}{ Sig } \\
\hline & & & & 0.05 & 0.01 & & & & 0.05 & 0.01 \\
\hline A0 & 2.55 & \pm & 0.092 & $a$ & A & 4.44 & \pm & 0.098 & A & $A$ \\
\hline A1 & 2.22 & \pm & 0.098 & b & B & 4.11 & \pm & 0.191 & B & $A B$ \\
\hline A2 & 2.05 & \pm & 0.092 & b & B & 3.83 & \pm & 0.000 & C & BC \\
\hline A3 & 2.07 & \pm & 0.115 & b & B & 3.61 & \pm & 0.092 & $\mathrm{Cd}$ & $C D$ \\
\hline A4 & 1.73 & \pm & 0.000 & c & C & 3.44 & \pm & 0.098 & De & DE \\
\hline A5 & 1.57 & \pm & 0.115 & C & C & 3.22 & \pm & 0.255 & $\mathrm{E}$ & $\mathrm{E}$ \\
\hline
\end{tabular}

Hasil uji BNT menunjukan bahwa konsentrasi konsentrasi $0 \%(\mathrm{~A} 0)$, memiliki nilai tertinggi dibanding dengan konsentrasi yang lain.

Maryanti (2014) menyatakan bahwa biji pepya mempunyai enzim proteolitik, serta komponen bioaktif seperti saponin, tanin, flavanoid, triterpenoid, yang berkhasiat sebagai anti jamur dengan merusak integritas dinding sel jamur. Triterpenoid bersifat toksik sehingga ketika senyawa aktif terserap oleh jamur patogen dapat menimbulkan kerusakan pada organel - organel sel, menghambat kerja enzim didalam sel dan pada akhirnya akan terjadi penghambatan pertumbuhan jamur patogen.

Tabel 2. Uji BNT keterjadian penyakit antraknosa hari ke-6 dan hari ke-8 pada buah cabai merah yang diperlakukan dengan berbagai konsentrasi ekstrak biji pepaya.

\begin{tabular}{|c|c|c|c|c|c|c|c|c|c|c|}
\hline \multirow{2}{*}{ Perlakuan } & \multirow{2}{*}{ M } & \multirow{2}{*}{ \pm} & \multirow{2}{*}{ Sd } & \multicolumn{2}{|l|}{ Sig } & \multirow{2}{*}{ M } & \multirow{2}{*}{ \pm} & \multirow{2}{*}{ Sd } & \multicolumn{2}{|l|}{ Sig } \\
\hline & & & & 0.05 & 0.01 & & & & 0.05 & 0.01 \\
\hline A0 & 44.44 & \pm & 5.092 & $a$ & $A$ & 84.44 & \pm & 3.845 & $a$ & A \\
\hline A1 & 38.88 & \pm & 3.851 & $a b$ & $A B$ & 74.44 & \pm & 5.092 & b & $A B$ \\
\hline A2 & 36.66 & \pm & 0.000 & bc & $A B C$ & 68.88 & \pm & 3.851 & bc & BC \\
\hline A3 & 33.33 & \pm & 3.330 & bcd & $\mathrm{BC}$ & 63.33 & \pm & 3.330 & $\mathrm{~cd}$ & $B C D$ \\
\hline A4 & 31.11 & \pm & 1.923 & $\mathrm{~cd}$ & BC & 59.99 & \pm & 5.774 & $\mathrm{~d}$ & $C D$ \\
\hline A5 & 27.77 & \pm & 5.092 & d & C & 55.55 & \pm & 3.851 & d & D \\
\hline
\end{tabular}

Tanpa pemberian ekstrak biji
pepaya menunjukan keterjadian
penyakit yang tinggi dibanding dengan
perlakuan yang lain.
Konsentrasi ekstrak daun
pepaya $5 \% \quad$ (A5) menunjukan

kemampuan yang tinggi dalam menekan perkembangan jamur $C$. acutatu namun berbeda dengan konsentrasi $0 \%(\mathrm{~A} 0)$ yang menunjukan keterjadian penyakit yang ttinggi. Menurut Martiasih (2014), biji pepaya 
diketahui mengandung senyawa kimia seperti golongan fenol, alkaloid, dan saponin. Biji pepaya yang berwarna putih mengandung senyawa triterpenoid aldehida dengan gugus fungsi: $-\mathrm{CH} 2,-\mathrm{CH} 3$, dan $\mathrm{C}=0$, yang mempunyai potensi anti bakteri. Menurut penelitian Mulyono (2013), biji pepaya memiliki senyawa alkaloid karpain. Karpain merupakan alkaloid yang memiliki cincin laktonat dengan 7 kelompok rantai metilen yang mampu untuk menghambat kinerja beberapa mikroorganisme. Karpain dapat mencerna protein dari mikro organisme dan mengubahnya menjadi pepton. Biji pepaya juga mengandung senyawa flavonoid. Senyawa ini juga memiliki daya antibakteri dengan mendenaturasi protein sel bakteri dan merusak membran selnya. Jadi senyawa senyawa anti bakteri tersebut diduga menurunkan keterjadian penyakit.

Tabel 3. Uji BNT keparahan penyakit antraknosa hari ke-6 dan hari ke-8 pada buah cabai merah yang diperlakukan dengan berbagai konsentrasi ekstrak biji pepaya.

\begin{tabular}{cccccccccccc}
\hline \multirow{2}{*}{ Perlakuan } & \multirow{2}{*}{$\mathrm{M}$} & \multirow{2}{*}{ \pm} & $\mathrm{S} d$ & \multicolumn{3}{c}{ Sig } & \multirow{2}{*}{$\mathrm{M}$} & \pm & $\mathrm{Sd}$ & \multicolumn{2}{c}{ Sig } \\
\cline { 5 - 6 } \cline { 5 - 8 } & & & & 0.05 & 0.01 & & & & 0.05 & 0.01 \\
\hline A0 & 40.0 & \pm & 0.00 & a & A & 80.00 & \pm & 0.000 & a & A \\
A1 & 40.0 & \pm & 0.000 & a & A & 71.11 & \pm & 10.183 & ab & AB \\
A2 & 40.0 & \pm & 0.00 & a & A & 62.22 & \pm & 3.845 & bc & BC \\
A3 & 35.55 & \pm & 3.851 & ab & A & 57.78 & \pm & 3.851 & cd & BC \\
A4 & 40.00 & \pm & 0.000 & a & A & 53.33 & \pm & 6.670 & cd & C \\
A5 & 31.11 & \pm & 7.702 & b & A & 48.88 & \pm & 3.851 & d & C \\
\hline
\end{tabular}

Pada hari ke-6 pada konsentrasi $0 \% \quad(A 0), 1 \% \quad(A 1), 2 \% \quad(A 2)$, dan $4 \%(A 4)$, memiliki nilai intensitas penyakit yang sama, sedangkan pada konsentrasi 5\% (A5) mempunyai nilai intensitas penyakit terendah. Pada hari ke-8 konsentrasi $0 \%(A 0)$, mempunyai nilai intensitas penyakit tertinggi dibandingkan dengan konsentrasi lainnya. Perbedaan yang nyata terlihat pada konsentrasi $0 \%(\mathrm{AO})$ dan $5 \%$
(A5), dimana konsentrasi $0 \%$ (A0) memiliki nilai intensitas penyakit yang lebih tinggi dibanding dengan 5\% (A5), hal ini menunjukan bahwa ekstrak etanol biji pepaya berpengaruh terhadap ketahanan serangan jamur C.acutatm pada buah cabai merah, kandungan yang terdapat pada ekstrak etanol biji pepaya mampu menghambat proses pertumbuhan jamur, sehingga jamur sulit untuk menyebar dan berkembang (Martiasih, 2014).

Tabel 4. Uji BNT susut bobot buah cabai sebelum diberi perlakuan sampai setelah diberi perlakuan.

\begin{tabular}{cccccc}
\hline \multirow{2}{*}{ Perlakuan } & \multirow{2}{*}{$M$} & \multirow{2}{*}{ \pm} & Sd & \multicolumn{2}{c}{ Sig } \\
\cline { 5 - 6 } & & & & 0.05 & 0.01 \\
\hline A0 & 80.00 & \pm & 0.000 & $\mathrm{~A}$ & $\mathrm{~A}$ \\
$\mathrm{~A} 1$ & 71.11 & \pm & 10.183 & $\mathrm{Ab}$ & $\mathrm{AB}$ \\
$\mathrm{A} 2$ & 62.22 & \pm & 3.845 & $\mathrm{BC}$ & $\mathrm{BC}$ \\
$\mathrm{A} 3$ & 57.78 & \pm & 3.851 & $\mathrm{Cd}$ & $\mathrm{BC}$ \\
$\mathrm{A} 4$ & 53.33 & \pm & 6.670 & $\mathrm{Cd}$ & $\mathrm{C}$ \\
$\mathrm{A} 5$ & 48.88 & \pm & 3.851 & $\mathrm{D}$ & $\mathrm{C}$ \\
\hline
\end{tabular}

Susut bobot buah pada konsentrasi $2 \%(A 2)$ memiliki nilai paling rendah di bandingkan dengan yang lainnya. Dan susut bobot buah paling tinggi pada konsentrasi $0 \% \quad(A 0)$. Susut bobot buah pada buah cabai disebabkan oleh proses respirasi dan transpirasi yang mengakibatkan kehilangan 
substrat dan air. Secara umum susut bobot buah cabai semakin meningkat dengan meningkatnya waktu penyimpanan pada semua tingkatan suhu. Menurut Znidarcic (2010). yang berbeda - beda. Nilai tertinggi terdapat pada perlakuan $0 \%(A 0)$.

\section{PEMBAHASAN}

Pada tahap awal infeksi konidia
Colletotrichum yang berada di permukaan kulit buah cabai merah akan berkecambah dan membentuk tabung perkecambahan. Setelah tabung perkecambahan berpenetrasi kelapisan epidermis kulit buah cabai merah maka akan membentuk jaringan hifa. Kemudian hifa intra dan interseluler menyebar keseluruh jaringan dari buah cabai merah (Photita dkk, 2005). Biji pepaya diketahui mengandung senyawa kimia seperti golongan fenol, alkaloid, dan saponin. Biji pepaya yang berwarna putih mengandung senyawa triterpenoid aldehida dengan gugus fungsi: $-\mathrm{CH} 2$, $\mathrm{CH} 3$, dan $\mathrm{C}=0$, yang mempunyai potensi anti bakteri. Biji pepaya mengandung suatu enzim papain yang merupakan suatu zat yang mampu merombak protein dari jamur $C$. acutatum.

Adanya enzim protease yang terdapat pada ekstrak biji pepaya, akan mengakibatkan kerja enzim pada $C$. acutatum terhambat. Menurut Juliantara (2012), zat aktif dalam biji pepaya adalah papain. Enzim papain merupakan enzim yang bersifat proteolitik yaitu mengkatalisis ikatan peptida pada protein menjadi senyawa - senyawa yang lebih sederhana seperti dipeptida. Hasil penelitian ini menunjukan bahwa ekstrak etanol biji pepaya tidak memberikan pengaruh terhadap susut bobot buah, hal ini menunjukan bahwa perlakuan ekstrak etanol biji pepaya tidak mampu menekan berkembangnya jamur $C$. acutatum. Perbedaan susut bobot buah tidak berbeda jauh, namun memiliki nilai

Susut bobot buah terjadi karena sebagian air dalam jaringan cabai hilang, kemungkinan disebabkan oleh proses respirasi dan transpirasi. Menurut Patria (2013), respirasi merupakan reaksi kimiawi dari buah yang mengubah gula yang dibantu dengan oksigen menjadi karbondioksida, air dan melepaskan panas. Panas yang dihasilkan cenderung meningkatkan suhu dari komoditas yang menyebabkan meningkatnya transpirasi. Meningkatnya transpirasi menyebabkan penyusutan berat cabai.

\section{KESIMPULAN}

Dari hasil penelitian ini disimpulkan bahwa ekstrak etanol biji pepaya (Carica papaya L.) memiliki pengaruh terhadap penyakit antraknosa yang disebabkan oleh jamur Colletoticum acutatum dengan efektivitasa yang lebih tinggi dibanding kontrol normal (0\%) dan konsentrasi ekstrak etanol biji pepaya sebesar $5 \%$ merupakan konsentrasi yang terbaik dalam menekan perkembangan penyakit antraknosa buah cabai mera yang disebabkan oleh jamur Colletotricum acutatum.

\section{SARAN}

Saran dalam penelitian ini yaitu, perlu dilakukan uji preventif lebih lanjut untuk mengetahui efektivitas ekstrak biji pepaya sebagai fungisida alami terhadap jamur Colletotrichum acutatum, penyebab penyakit antraknosa pada buah cabai merah.

\section{DAFTAR PUSTAKA}

Fuadi, I. dan R. Yusuf. 2005. Penerapan System Pengendalian Hama

TerpaduPadaTanamanCabe.

Sagu: 1-5. 
Martiasih,

M.

2014.

AktivitasAntibakteriEkstrakBijiPep

ayaterhadapEscherichia coli

danStreptococcus pyogenes.

(Skripsi).

JurusanBiologiFakultasTeknobiolo

gi. UniversitasAtma Jaya

Yogyakarta.

Maryanti E, Febriyani E, Lestari E. 2014.

StudiEfektivitasAntijamurNanopar tikelZnO/ZnSTerhadapPertumbuh anJamurPityrosporumovalePenye babKetombe. Gradien [Internet]. 2014 [diakses 6 Februari 2017]; 10(2). Tersediadi : https://ejournal.unib.ac.id/index .php/gr adien/article/vi $\mathrm{ew} / 347 / 286$

Mulyono, L.M.

2013.

AktivitasAntibakteriEkstrakEtanol

BijiBuahPepaya (Carica papaya L.) Terhadap Escherichia coli dan Staphylococcus aureus. JurnalIImiahMahasiswaUniversitas Surabaya, 2 (2), 1,6,7.

Nur 'Aini, F., S. Sukamto., Wahyuni., R.G. Suhesti., dan Q. Ayunin. 2013. PenghambatanPertumbuhanCollet otrichumacutatumolehTrichoderm aharzianum, Trichodermakoningii, Bacillus subtilisdan Pseudomonas fluorescens. Pelita Perkebunan. 29: $44-52$.

Setiadi. 20011. BertanamCabai. Jakarta :PenebarSwadaya. 183 hal

Znicdarcic D, Ban II D, Milan O, M, Karic L, Pozra T. 2010. Influence of postharvest temperatures on physicochemical quality of tomatoes (Lyscopersicon esculentum Mill.). Jurnal of Food, Agriculture and Environment. 